\title{
Article \\ The Influence of Quality Management System on the Operation of Periodical Technical Inspection Stations
}

\author{
Juraj Hudec $^{1,2}$, Branislav Šarkan ${ }^{2, * \mathbb{D}}$, Renáta Czödörová ${ }^{1,2}$ and Jacek Caban ${ }^{3, * \mathbb{C}}$ \\ 1 Department of Audit, State Supervision and Oversight Ministry of Transport and Construction of the Slovak \\ Republic, 81005 Bratislava, Slovakia; juraj.hudec@mindop.sk (J.H.); rczodorova@gmail.com (R.C.) \\ 2 Faculty of Operation and Economics of Transport and Communications, University of Žilina, \\ 01026 Žilina, Slovakia \\ 3 Faculty of Mechanical Engineering, Lublin University of Technology, 20-618 Lublin, Poland \\ * Correspondence: branislav.sarkan@fpedas.uniza.sk (B.Š.); j.caban@pollub.pl (J.C.)
}

check for updates

Citation: Hudec, J.; Šarkan, B.;

Czödörová, R.; Caban, J. The

Influence of Quality Management System on the Operation of Periodical Technical Inspection Stations. Appl. Sci. 2021, 11, 4854. https://doi.org/ 10.3390/app11114854

Academic Editor: Carla Raffaelli

Received: 27 April 2021

Accepted: 21 May 2021

Published: 25 May 2021

Publisher's Note: MDPI stays neutral with regard to jurisdictional claims in published maps and institutional affiliations.

Copyright: (c) 2021 by the authors. Licensee MDPI, Basel, Switzerland. This article is an open access article distributed under the terms and conditions of the Creative Commons Attribution (CC BY) license (https:// creativecommons.org/licenses/by/ $4.0 /)$.

\begin{abstract}
This article deals with the minimum requirements for quality management at Periodical Technical Inspection Stations (PTIS) for road vehicles in the Slovak Republic, as well as in selected countries of the European Union. Specifically, it contains research performed at all of the PTIS in the Slovak Republic with a focus on the established quality management system and the number of employees of companies operating these PTIS, as well as similar research in selected countries of the European Union. Based on the research results, the article contains an assessment of the influence of the implemented quality management system on the operation of PTIS. The analysis of the results showed that $86.7 \%$ of PTIs have an established system to meet the minimum requirements for quality management through a documented procedure (internal regulation), and $13.3 \%$ of the PTI have the certified quality management system according to the STN EN ISO/IEC 9001 standard. Unfortunately, no PTI in the Slovak Republic has the fulfilment of quality management requirements according to the standard STN EN ISO/IEC 17020.
\end{abstract}

Keywords: technical inspection; operation of vehicles; road traffic safety; technical malfunction

\section{Introduction}

The concept of quality is a decisive business phenomenon these days. There is absolutely no way to conduct business without ensuring proper quality [1]. It is an expression of the universality of a product or service to fully satisfy the needs of the customer [2]. The demand for production quality appeared in the 1950s and its importance continued to grow [3]. Its evaluation has gradually become a determining factor in competitiveness [4]. While today prices are easy to compare, it is much more complicated to compare quality levels. Quality is not only the basis for commercial success in the market, but it is also the bearer of overall business prosperity, because at present only quality can guarantee the economically efficient sale of products or services in competitive markets [5]. The importance of the concept of quality and its management stems from commercial, economic, but also other outcomes and benefits that the quality of products or services brings about [6]. Quality is a summary of the features and characteristics of a product through which an object acquires the ability to meet the intended and expected needs [7].

The task of quality management is to ensure that the requirements for product quality and production or development processes are among the main priorities of the company [8]. These requirements can be formally defined (for example by internal guidelines, quality manual) or informal (unwritten expectations of the appropriate quality). Quality management deals not only with production [9-13] or development processes and the product itself [14], but also extends to the management of the company and attempts to evaluate the management of the company and projects $[15,16]$, the success of strategic decisions 
and environmental [17] and many other things. The existence of an unambiguously recognized reference quality management system creates a very accurate evaluation tool. The development of quality management has recently led to several more or less standardized procedures, some of which are adopted in the form of standards or recommendations [18]. A very important issue represented in the literature is the quality management systems of transport processes [19,20] and safety management systems in transport [21]. The latter aspect concerns a very wide spectrum of activities, including legal and educational aspects [22,23], social [24-26], road traffic safety [27-32], general safety of the transport system [33-38], and resulting from the use and operation of means of transport [39-45]. Moreover, concerning technical safety [46], as well as related to technical and legal control through actions of the Police and Transport Inspection and other services.

The development of the automotive industry due to the growing demand for vehicles for private or business purposes contributes to the need to control the technical condition of these vehicles, which contributes to the safe operation of vehicles. Vehicles in good technical condition are then a prerequisite for performing their transport task at a high level.

One of the functions of the state is to protect the lives and property of citizens. Every state has an interest in ensuring that vehicles in traffic do not endanger road traffic safety and the environment. Therefore, the minimum technical requirements that must be met by every vehicle in road traffic have been set and, in connection with this, the introduction of periodical inspections of the technical condition of vehicles, which is carried out at periodical technical inspection stations (PTI). The obligation to set up a system of periodical technical inspections applies to each EU Member State, as well as to complying with the minimum requirements for this system under the relevant EU directive.

However, the primary goal of the state is to ensure that the technical condition of vehicles is assessed as objectively as possible and thus that only vehicles that are realistically roadworthy for road traffic are operated on roads. Therefore, the results of the assessment of the technical condition of vehicles by periodical technical inspection stations, namely the temporary roadworthiness and non-roadworthiness of vehicles for road traffic, are a parameter that is very closely monitored.

PTI is a workplace specialized in performing technical inspections. A technical inspection is an inspection and assessment of the technical condition of a vehicle, systems, components or separate technical units. PTI therefore provides services in the form of evaluation of the technical condition of the vehicle. According to Article 12 sub-point 2 of Directive 2014/45/EU of the European Parliament and Council of 3 April 2014 on regular roadworthiness tests for vehicles and their trailers and repealing Directive 2009/40/ES (afterwards referred to as "Directive 2014/45/EU"), PTI must meet the minimum quality management requirements by ensuring compliance with the requirements set by the approving Member State [47]. Based on the above, the Member States of the European Union have legislatively introduced minimum quality management requirements for the PTI of the given state.

The purpose of this article is to examine the impact of the established quality management system on the results of the assessment of the technical condition of vehicles at Technical Inspection Stations in the Slovak Republic, as well as in the selected ten countries of the EU. The article also includes testing of statistical hypotheses focusing on whether the difference between the average percentage of temporary roadworthy and not roadworthy vehicles, evaluated at a PTI with certification or accreditation according to ISO standard and at a PTI without this certification or accreditation, is significant.

The main goal of the paper is to demonstrate the measurable impact of quality management on the quality of PTI activities.

\section{Minimum Requirements for Quality Management at the PTI in the Slovak Republic}

Based on the requirements of Directive 2014/45/EU, the Slovak Republic has adopted a law into its legal system which, among other things, sets the minimum requirements for quality management at the PTI in the Slovak Republic. According to the relevant provisions 
of this law, the approval authority shall authorize those individuals who meet the minimum requirements for quality management to carry out a technical inspection. The minimum requirements for PTI quality management are a set of organizational measures, activities and tools that ensure in writing the verifiability of the fulfilment of proper procedures during technical inspection.

Fulfilment of the minimum requirements for PTI quality management has to be shown in three ways, namely:

(a) Documented procedure (internal regulation), which:

1. Includes the checking of the correctness of the issuing documents on roadworthiness testing, stamping, signing and confirmation of acquaintance of the vehicle operator or driver of the vehicle with the result of the roadworthiness test.

2. Determines the responsibilities of individual employees.

3. Determines voluntary training of individual employees with the aim to increase quality.

4. Determines the procedure for the handling of complaints.

5. Determines the regular periods of internal control, determines the form of output from the performed internal control.

6. Determines the procedure for ensuring the security of the use of the national information system.

(b) A valid accreditation certificate, issued by the Slovak National Accreditation Service, proving compliance with the requirements for the activities of inspection authorities as a type " $\mathrm{A}$ " inspection authority according to STN EN ISO/IEC 17020 Conformity Assessment $[48,49]$.

(c) A valid certificate proving the established management system and production quality, for example according to the standard STN EN ISO 9001 Quality Management Systems [50-52].

\section{Survey on the Implemented Quality Management System at the PTI in the Slovak Republic}

As of 30 September 2020, 158 PTIs were operational in the Slovak Republic [53]. There were 21 PTIs in the Bratislava Region, 21 in the Trnava Region, 15 in the Trenčín Region, 19 in the Nitra Region, 16 in the Žilina Region, 23 in the Region of Banská Bystrica, 21 in the Region of Prešov and 22 PTIs in the Košice Region. A survey was conducted at each PTI with a focus on the established quality management system and the number of employees of the companies operating the PTI. The following results were concluded at every PTI in the Slovak Republic [54].

Concerning the number of employees, they vary from 3 to 4,5 to 9,10 to 19,20 to 24 , 25 to 49,50 to 99 , and 100 to 149 employees. The number of employees was determined for the whole companies that operate the PTI, so not only the number of employees of the given PTI [55]. For the results of the survey concerning the individual regions see in the Table 1.

The above table shows that out of the complete number of 158 PTIs, 137 of them meet the minimum requirements for quality management by a documented procedure (by drafting an internal regulation), which represents an $86.7 \%$ share. Twenty-one PTIs have the certified quality management system according to the STN EN ISO/IEC 9001 norm, which represents $13.3 \%$. Fulfilment of quality management requirements according to the STN EN ISO/IEC 17020 norm standard was not documented by any PTIs.

Among other things, this may be due to the fact that meeting the minimum requirements for quality management by a documented procedure (by internal regulation) is the simplest and cheapest solution for PTIs, as this requires only one-time elaboration of one internal regulation for all activities performed, without their verification by any authority, and thus without any motivation to improve or change anything. Basically, it is only a formal fulfilment of the minimum requirements for quality management without any added value. 
Table 1. Numbers of PTIs in individual regions of the Slovak Republic based on the fulfilment of quality management requirements.

\begin{tabular}{cccccccccc}
\hline $\begin{array}{c}\text { Method of Meeting the } \\
\text { Requirements for Quality } \\
\text { Management at the PTI }\end{array}$ & Bratislava & Trnava & Trenčín & Nitra & Žilina & $\begin{array}{c}\text { Banská } \\
\text { Bystrica }\end{array}$ & Prešov & Košice & All \\
\hline $\begin{array}{c}\text { documented procedure } \\
\text { (internal regulation) }\end{array}$ & 17 & 20 & 13 & 15 & 14 & 21 & 18 & 19 & 137 \\
ISO/IEC 17020 & 0 & 0 & 0 & 0 & 0 & 0 & 0 & 0 \\
STN EN ISO 9001 & 4 & 1 & 2 & 4 & 2 & 2 & 3 & 3 \\
All & 21 & 21 & 15 & 19 & 16 & 23 & 21 & 22 & 158 \\
\hline
\end{tabular}

Furthermore, companies operating PTI, which have an established system of meeting the minimum requirements for quality management by a documented procedure (by internal regulation) and a quality management system according to STN EN ISO/IEC 9001, have the following number of employees shown on Figure 1.

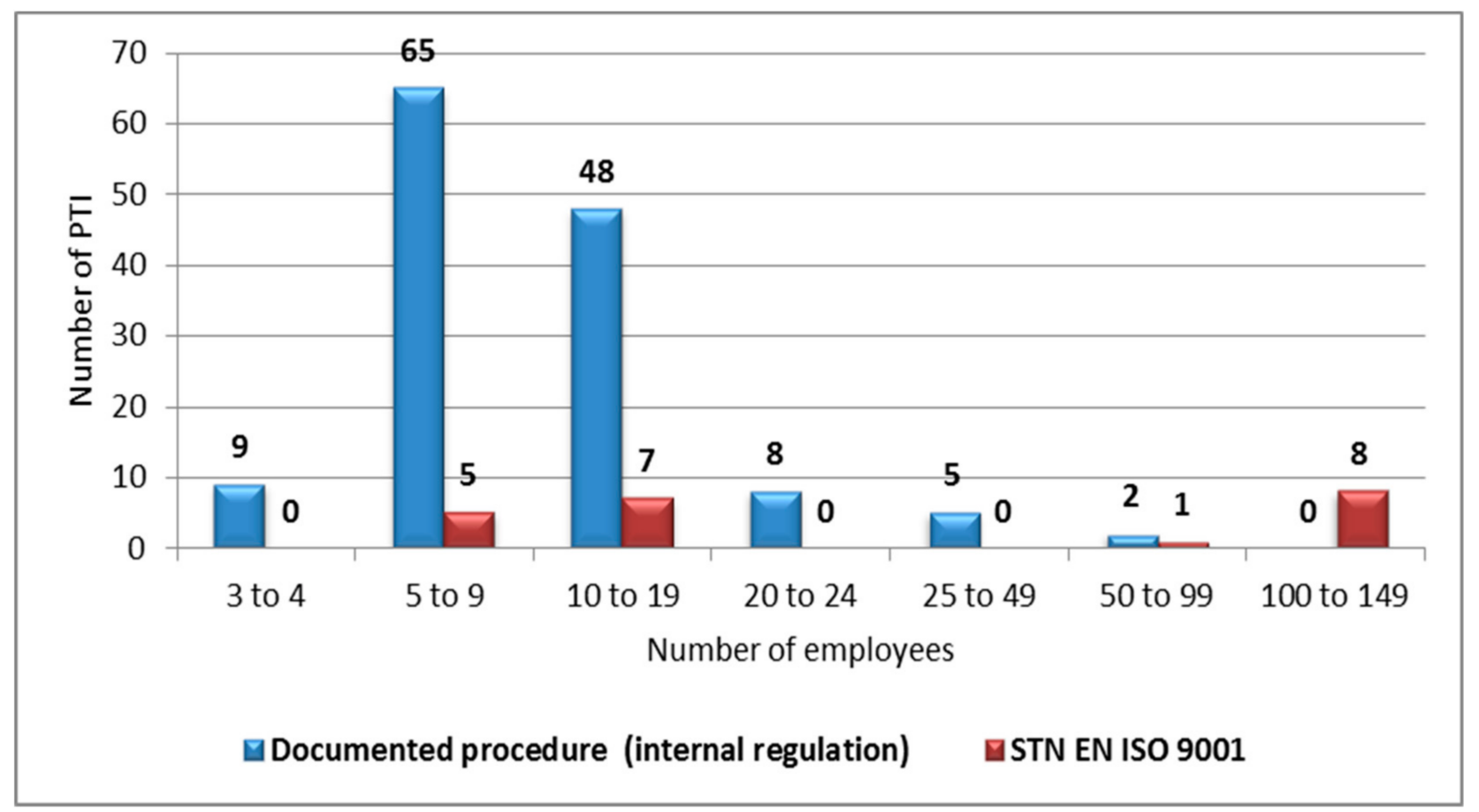

Figure 1. Number of companies operating PTIs by number of employees and fulfilment of quality management requirements. Source: Author according to [56].

From the table it follows that the largest number of companies operating PTIs, which have a quality management system in place by a documented procedure (by internal regulation) have 5 to 9 employees and the smallest number of companies operating PTIs have 50 to 99 employees. On the contrary, the largest number of companies operating PTIs, which have an established quality management system according to STN EN ISO/IEC 9001, have 100 to 149 employees and the smallest number have 50 to 99.

Furthermore, it follows from the data given in the table that most companies operating PTIs have 5 to 9 employees, which represents a $44.3 \%$ share. The smallest companies operating PTIs have 50 to 99 employees, which represents 1.9\%.

\section{Evaluation of Technical Condition of Vehicles at the PTI}

During roadworthiness tests in each Member State of the EU, the technical condition of the vehicle and the function of the individual systems, components and separate 
technical units must be checked according to the individual control items listed in Annex no. 1 of Directive no. 2014/45/EU and within the minimum set scope of the following controlled areas:

0. Vehicle identification;

1. Breaking equipment;

2. Steering control;

3. Clarity of view from the inside;

4. Lights equipment and parts of the electrical system;

5. Vehicle axles, wheels, tires, suspension;

6. Chassis and its accessories;

7. Other equipment;

8. Environmental impact;

9. Additional checks on vehicles of categories M2 and M3 intended for passenger transport $[57,58]$.

Each control item has its own unique code (which is valid equally in each Member State of the EU) and each control item is assessed with a specified minimum defect severity.

During the roadworthiness test at the PTI, the technical condition of the vehicle and the function of individual systems, components and separate technical units are assessed by defects belonging to the following groups of defects:

(a) Minor defects, which do not affect the safety of the vehicle or the environment, as well as other minor non-conformities; the vehicle is "roadworthy for operation in road traffic";

(b) Major defects, which may affect the safety of the vehicle or the environment or pose a threat to other road traffic users, as well as other major cases of non-compliance; the vehicle is "temporarily roadworthy";

(c) Dangerous defects, which present a direct and immediate risk to road safety or have an impact on the environment and the use of the vehicle in road traffic must be prohibited; the vehicle is "not roadworthy for road traffic".

A vehicle on which defects belonging to more than one group of defects are found shall be evaluated according to the defect that is found as the most serious. A vehicle with multiple defects within the same control area as defined by the scope of control may be assigned to the nearest group of more serious defects if it can be demonstrated that the combined effect of these defects results in a higher degree of road safety hazard.

The final PTI product is therefore an evaluation of the technical condition of the vehicles [59]. However, the provision of this service is not a normal business but the safeguarding of the state's interest [60]. For this reason, the statistical results of technical inspections, given in particular the temporary roadworthiness and not roadworthiness of vehicles for road traffic, are closely monitored by the PTI inspection authorities and are considered as an indicator of the quality of the given PTI. The higher the percentage of temporary roadworthy and not roadworthy vehicles, the better the activity of the given PTI [61,62].

Even a very low number of vehicles evaluated in this way at a PTI is considered to be a risk criterion that gives reason to exercise control over that PTI [63].

\section{The Influence of the Introduction of Quality Management System on the Results of PTI in Slovak Republic}

A research was carried out in the Slovak Republic in connection with the quality management system of PTIs. For this purpose, all PTIs of the Slovak Republic were divided into two groups, depending on the method of meeting the requirements for quality management (PTIs that have a quality management system introduced by a documented procedure (internal regulation) and PTIs that have implemented a quality management system according to STN EN ISO 9001). Subsequently, it was determined with what average percentage of temporary roadworthiness and not roadworthiness were the vehicles technical condition for road traffic assessed by all PTIs that have a quality management 
system introduced by a documented procedure (internal regulation) (number: 137) and with what average percentage were assessed the technical condition of vehicles by all PTIs that have implemented a quality management system according to STN EN ISO 9001 (number: 21). The mentioned research was performed by means of data stored in the automated information system of technical inspections for the period of 2019 and 2020 [64]. The results are recorded in the Table 2.

Table 2. Results of the evaluation of vehicles at PTI depending on the method of meeting the requirements for quality management; Source: Author according to [65].

\begin{tabular}{|c|c|c|}
\hline Year & $\begin{array}{l}\text { The Average Rate of Assessment of } \\
\text { Temporary Roadworthiness and } \\
\text { Not Roadworthiness of Vehicles for } \\
\text { Road Traffic Use, Assessed by the } \\
\text { PTI, Which Fulfil the Minimum } \\
\text { Requirements for Quality } \\
\text { Management by a Documented } \\
\text { Procedure (Internal Regulation) }\end{array}$ & $\begin{array}{l}\text { The Average Rate of Assessment of } \\
\text { Temporary Roadworthiness and Not } \\
\text { Roadworthiness of Vehicles for Road } \\
\text { Traffic Use, Assessed by the PTI, } \\
\text { Which Fulfil the Minimum } \\
\text { Requirements for Quality } \\
\text { Management According to } \\
\text { STN EN ISO } 9001\end{array}$ \\
\hline 2019 & $12.52 \%$ & $14.17 \%$ \\
\hline 2020 & $12.84 \%$ & $14.57 \%$ \\
\hline
\end{tabular}

As the data in the Table 2 show, the PTIs that had a quality management system according to STN EN ISO 9001 assessed the technical condition of vehicles on average with a higher degree of temporary roadworthiness and not roadworthiness than PTIs that had a quality management system based on a documented procedure (internal regulation). At the same time, out of twenty one periodical technical inspection stations certified according to STN EN ISO 9001, sixteen of them (76\%) have an established electronic booking system for customers who can use it to book an appointment for technical or emission inspection, which provides greater comfort for the customers. The significance of this difference can also be verified by statistical research.

Based on statistical data on temporary roadworthiness and not roadworthiness of vehicles for road traffic, it is possible to establish the hypothesis (H1) that for the period of 2019-2020 in the Slovak Republic, the difference between the average percentage of temporarily roadworthy and not roadworthy vehicles of all PTIs which are certified according to ISO 9001 and PTIs without this certification is significant, against the hypothesis that this difference is not significant (Ho). So for this reason, statistical research will be carried out in the form of tests, performed on these two groups of values in the Data Analysis application in MS Excel program. One group shall represent the average results of the evaluation of PTI vehicles with ISO 9001 certification for the period 2019-2020, the other group shall represent the average results of the evaluation of PTI vehicles without ISO 9001 certification in the same period. Before performing the $t$-Test, an F-Test will be performed to compare the variance of the two groups of data, in order to select the correct $t$-Test. The results of the F-Test are shown in the Table 3.

Table 3. Results of F-Test for variances.

\begin{tabular}{ccc}
\hline & $\begin{array}{c}\text { F-Test Two-Sample for Variances } \\
\text { Variable 1 }\end{array}$ & Variable 2 \\
\hline Mean & 12.67635036 & 14.36952381 \\
Variance & 10.15508511 & 8.430314762 \\
Observations & 137 & 21 \\
df & 136 & 20 \\
F & 1.204591453 & \\
P(F $\leq$ f) one-tail & 0.32628342 & \\
F Critical one-tail & 1.890238594 & \\
\hline
\end{tabular}


The results of this test indicate that with a reliability of $95 \%$, the zero hypothesis is accepted that the two groups of data have the same deviations (because the $p$-value is greater than 0.05).

Based on the result of the F-Test, a $t$-Test was selected for comparison of averages, assuming the same deviations of the two groups of PTI data with and without the ISO standard. The result of this test is recorded in the Table 4.

Table 4. State comparison $t$-Test results.

\begin{tabular}{ccc}
\hline \multicolumn{1}{c}{$\boldsymbol{t}$-Test Two-Sample Assuming Equal Variances } & Variable 1 & Variable 2 \\
\hline Mean & 12.67635036 & 14.36952381 \\
Variance & 10.15508511 & 8.430314762 \\
Observations & 137 & 21 \\
Pooled Variance & 9.933960708 & \\
df & 0 & \\
T Stat & 156 & \\
Hypothesized Mean Difference $\leq \mathrm{t})$ one-tail & -2.292353641 & \\
$\mathrm{t}$ Critical one-tail & 0.011610975 & \\
$\mathrm{P}(\mathrm{T} \leq \mathrm{t})$ two-tail & 1.654679996 & \\
$\mathrm{t}$ Critical two-tail & 0.02322195 & \\
\hline
\end{tabular}

The results of the $t$-Test show that the $p$ value $(0.023)$ is less than 0.05 . This means, with $95 \%$ reliability the average percentage of temporarily roadworthy and not roadworthy vehicles of all PTIs in the Slovak Republic in the period of 2019-2020 which are certified according to ISO 9001, and the average percentage of all PTIs without this certification, is significantly different and therefore hypothesis H1 is accepted.

\section{The Influence of the Introduction of Quality Management System on the Results of} PTI in Selected Countries of the European Union

Additionally, a survey was carried out on the pattern of eleven European Union countries (Austria, Germany, Poland, Estonia, Finland, Slovak Republic, the Czech Republic, Latvia, Sweden, Spain, and Ireland), whose authorities were willing to cooperate. For these countries the average results of the technical condition of the vehicles registered for PTI check in the given countries in 2019 were assessed and examined (temporarily roadworthy and not roadworthy vehicles for road traffic use) in relation to the obligation to introduce certification or accreditation according to the ISO standard at the PTI of the given country. The results are recorded in the table in Figure 2.

The above inquiry found that in the six countries, in which the PTI achieved the highest level of assessment of the technical condition of vehicles as temporarily roadworthy and not roadworthy for road traffic use (Spain, Germany, Sweden, Finland, Ireland, and Latvia) it is mandatory for PTIs to be accredited or certified according to the ISO standard (most often it is ISO/IEC 17020). The significance of this difference can also be demonstrated by statistical research. 


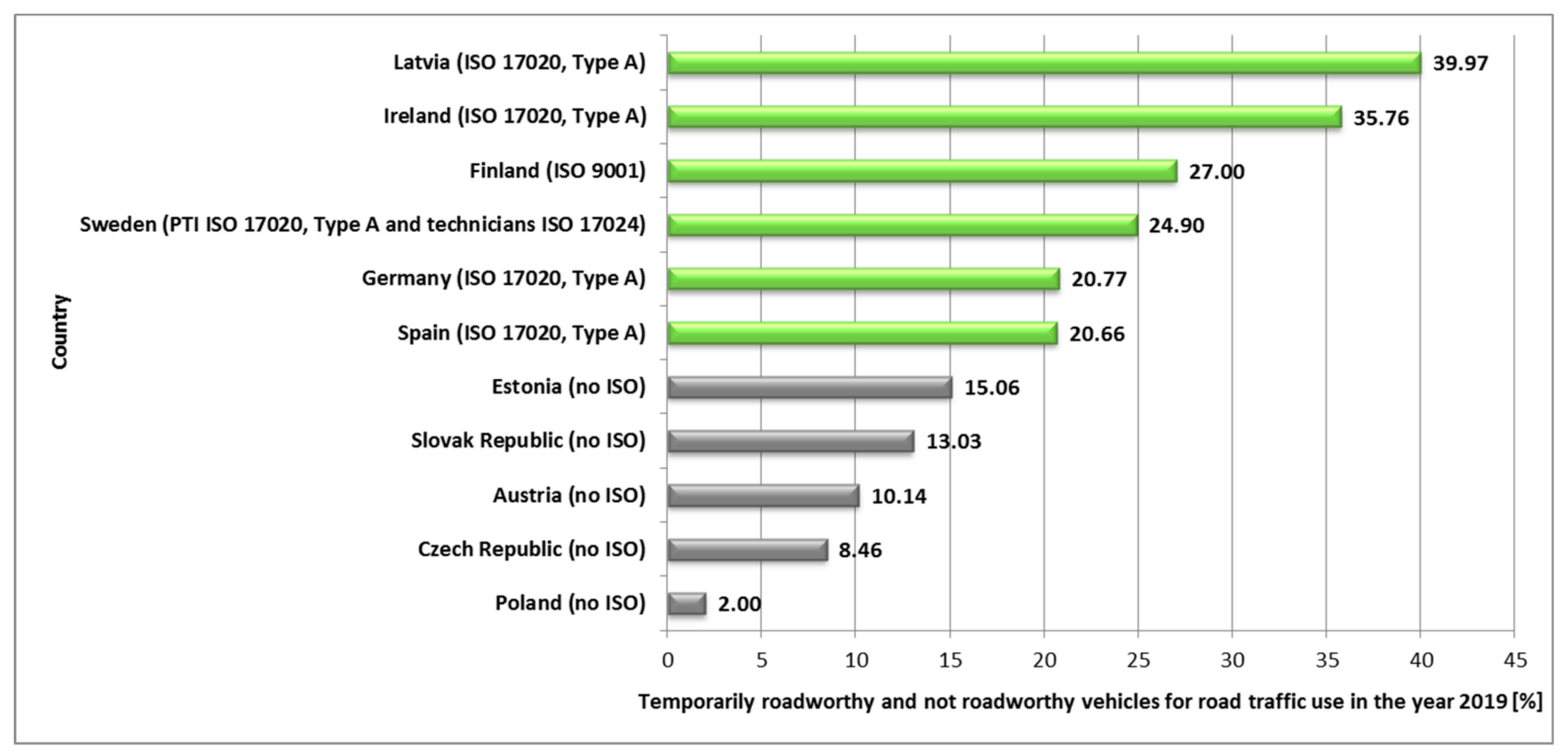

Figure 2. Average results of assessments of the technical condition of vehicles in selected countries of the European Union and the obligation of certification or accreditation at the PTI.

Based on the data shown in Figure 1 it is possible to establish the hypothesis (H1) that the difference between the average percentage of temporarily roadworthy and not roadworthy vehicles of all states in which PTIs are compulsorily accredited or certified according to ISO standard and states without this accreditation or certification, is significant against the hypothesis that this difference is not significant (Ho). So, for this reason, statistical research will be carried out in the form of tests, performed on these two groups of values in the Data Analysis application in MS Excel program. In one group, the average results of the evaluation of PTI vehicles of countries with accreditation or certification according to the ISO standard and in the other group will be the average results of the evaluation of PTI vehicles of countries without accreditation or certification according to the ISO standard. Before performing the $t$-Test, an F-Test will be performed to compare the variance of the two groups of data in order to select the correct $t$-Test. The results of the F-Test are shown in the Table 5.

Table 5. Results of F-Test for variances.

\begin{tabular}{ccc}
\hline & $\begin{array}{c}\text { F-Test Two-Sample for Variances } \\
\text { Variable 1 }\end{array}$ & Variable 2 \\
\hline Mean & 9.738 & 28.17666667 \\
Variance & 25.20812 & 64.01394667 \\
Observations & 5 & 6 \\
df & 4 & 5 \\
F & 0.393791061 & \\
P(F $\leq$ f) one-tail & 0.193727871 & \\
F Critical one-tail & 0.159845104 & \\
\hline
\end{tabular}

The results of this test indicate that with a reliability of $95 \%$, the zero hypothesis is accepted that the two groups of data have the same deviations (because the $p$-value is greater than 0.05).

Based on the result of the F-Test, a $t$-Test was selected for comparison of averages, assuming the same deviations of the two groups of PTI data with and without the ISO standard. The result of this test is recorded in the Table 6. 
Table 6. State comparison $t$-Test results.

\begin{tabular}{ccc} 
& $\boldsymbol{t}$-Test Two-Sample Assuming Equal Variances & Variable 1 \\
Mean & 9.738 & Variable 2 \\
Variance & 25.20812 & 28.17666667 \\
Observations & 5 & 64.01394667 \\
Pooled Variance & 46.76691259 & 6 \\
df & 0 & \\
t Stat & 9 & \\
Hypothesized Mean Difference & -4.45271038 & \\
t Critical one-tail & 0.000796972 & \\
$\mathrm{P}(\mathrm{T} \leq \mathrm{t})$ two-tail & 1.833112933 & \\
$\mathrm{t}$ Critical two-tail & 0.001593944 & \\
\hline
\end{tabular}

The results of the $t$-Test show that the $p$ value (0.00159) is less than 0.05 . This means that with a reliability of $95 \%$, the average percentage of temporarily roadworthy and not roadworthy vehicles in all countries in which PTI is compulsorily accredited or certified according to the ISO standard and the percentage of countries with PTI without this accreditation or certification is significantly different and therefore hypothesis $\mathrm{H} 1$ is accepted.

The above inquiry also shows us that certification according to STN EN ISO 9001, or the even higher accreditation according to ISO/IEC 17020 (most suitable for the subject of PTI activity) has a positive impact on the quality of PTI activity, and should therefore be introduced in the Slovak Republic, as well as other states of the European Union legally stipulated for PTI, as an obligation, not solely as an alternative.

This also has a rational justification. PTI, which obtained an ISO certificate or accreditation, has already met the demanding criteria of the norm. In preparation for obtaining a certificate or accreditation, it is necessary to develop a system. The basis is to determine the structure of the company, create clear rules, appoint responsible employees, optimize processes, and harmonize them with applicable legislation so that the PTI works with the highest possible quality [66]. This will ultimately make the whole process of PTI activities clearer, simpler and more efficient. Subsequently, PTI is forced to constantly improve and perfect its system of management, communication, documentation, personal data protection, the process of providing services, compliance with methodological instructions, and so on. Because of the reason that the certificate or accreditation is limited by the period of validity and the fulfilment of obligations are controlled by audits and inspections, the PTI is therefore forced to constantly maintain good quality standards [67]. In addition, the process of obtaining certification or accreditation is not at all simple or cheap, so for this reason every company is highly motivated to follow approved procedures and standards in order to avoid the loss of certification or accreditation.

Finally, it should also be mentioned that the introduction of certification or accreditation of the company according to the ISO standard is also a kind of accompanying phenomenon of responsible approach and attention of the company's management to their own company, which is then positively reflected in other activities of this company $[68,69]$.

The importance of accreditation for PTI is even expressed by the legislation of the European Union, since according to the provisions of Article 14 par. 4 Directive 2014/45/EU, it is not needed to have a system of national supervision of the PTI in a given Member State if the Member State concerned requires that the PTI be accredited in accordance with Regulation (ES) No 765/2008 [47]. This is the case which applies in Spain, Germany, and Sweden, where the PTI is not subject to state professional supervision through public authorities, but only to supervision from the level of the accreditation authority, and measures are taken to remedy any non-compliance. If the discrepancies are not eliminated, PTI may lose accreditation, and thus also the right to perform its activities. 


\section{Discussion of the Results}

The investigation was started on the impact of the implemented quality management system of the PTI on the evaluation of the technical condition of vehicles at these PTIs, showed that the PTI with established quality management system according to STN EN ISO 9001 on average assessed the technical condition of vehicles with a higher degree as temporary roadworthy and not roadworthy for road traffic as opposed to the PTI which met only the minimum requirements for quality management by a documented procedure (internal regulation).

Further research revealed that of the selected eleven Member States of the European Union, the first six countries in which PTK achieved the highest average rate of temporary roadworthiness and not roadworthiness of vehicles for road traffic, were compulsorily accredited or certified according to ISO standards (most often ISO/IEC 17020). Both of the cited research findings can be considered a positive phenomenon, as this excludes more technically not roadworthy vehicles from the road traffic, which pose a potential threat to safety or to the environment.

Since the above research shows that certification according to STN EN ISO 9001, or the even higher accreditation according to ISO/IEC 17020 has a positive impact on the quality of PTI activity, it would be absolutely necessary to introduce legislation for PTI in the Slovak Republic as well as in other Member States of the European Union concerning the obligation of accreditation according to (as it is the most suitable for the activities

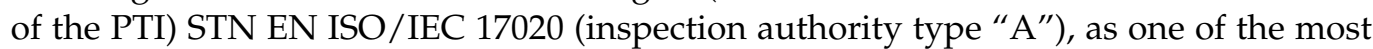
effective measures to improve the quality of the PTI activities. Due to the fact that the quality indicator of the PTI is given by the highest possible percentage of vehicles assessed at the PTI as temporarily roadworthy or not roadworthy for road traffic, the higher quality of the PTI activity results in less technically not roadworthy vehicles in road traffic and thus higher road safety.

However, it is debatable whether the better quality of PTI activities is directly related only to the established quality management system according to the ISO standard, or it is also the result of several systematic measures that are applied together with quality management in organizations. It is probable that organizations that are interested in improving the quality of their activities also employ other means to achieve this goal, and the accompanying phenomenon is accreditation or certification according to the ISO standard. Given that there is almost no research or work in this area, it is almost impossible to answer this question unambiguously. Therefore, in the future, research could be carried out focusing on whether other procedures or management methods different from the PTI without this certification or accreditation are applied to the PTI with certification or accreditation according to the ISO standard.

As for the overall quality of PTI's activities in the Slovak Republic, it should be mentioned that it has improved rapidly over time, even though it still does not reach the level of more advanced European countries. This was mainly due to the introduction of a camera system at the PTI, through which the supervisory authorities control the technicians ${ }^{\prime}$ activities and when discovered, they are sanctioned for violations. However, the rate of detected violations of regulations and fraud by PTI technicians in the Slovak Republic is still high. On the other hand, it is also necessary to mention that the rate of traffic accidents due to technical errors of vehicles is very low in the Slovak Republic. Whether this is a consequence of the activities of PTIs or just the consequence of a methodology for determining such accidents is debatable and justifies the need for further research in this topic.

\section{Conclusions}

This article has described the methods of meeting the minimum requirements for quality management of the PTI in the Slovak Republic (documented procedure (internal regulation), STN EN ISO 9001 or ISO/IEC 17020), set by the relevant legislation, as well as its other contexts. Subsequently, a survey was conducted on the implemented quality 
management systems and the number of employees at all PTIs in the Slovak Republic. This survey showed that $86.7 \%$ of PTIs have an established system to meet the minimum requirements for quality management through a documented procedure (internal regulation) and the largest number of them have between 5 and 9 employees. A total of $13.3 \%$ of the PTI have the certified quality management system according to the STN EN ISO/IEC 9001 standard and the largest number of them has between 100 and 149 employees. No PTI in the Slovak Republic has the fulfilment of quality management requirements according to the standard STN EN ISO/IEC 17020.

It follows from the above that companies operating PTI with a lower number of employees prefer a system of meeting the minimum requirements for quality management by a documented procedure (internal regulation) and companies with a higher number of employees prefer a certified quality management system according to STN EN ISO/IEC 9001. In conclusion, it is also necessary to add that documenting the fulfilment of the minimum requirements for quality management by a documented procedure (internal regulation) represents the simplest and cheapest alternative for PTI, which influences the decision for such a choice. Unfortunately, it is only a formal fulfilment of quality management requirements and is not an equivalent alternative to the ISO norm.

Author Contributions: Conceptualization, J.H. and B.Š.; methodology, B.Š. and R.C.; software, R.C.; validation, B.Š., R.C., and J.C.; formal analysis, J.H. and R.C.; investigation, J.H., B.Š., R.C., and J.C.; resources, J.H. and B.Š.; data curation, J.H. and R.C.; writing-original draft preparation, J.H., B.Š., R.C., and J.C.; writing-review and editing, J.H., B.Š., R.C., and J.C.; visualization, J.C.; funding acquisition, B.S. All authors have read and agreed to the published version of the manuscript.

Funding: This research received no external funding.

Institutional Review Board Statement: Not applicable.

Informed Consent Statement: Not applicable.

Data Availability Statement: Not applicable.

Conflicts of Interest: The authors declare no conflict of interest.

\section{References}

1. Konečný, V. Nástroje a metódy manažérstva kvality. In Návody na Cvičenia z Premetu Manažment Kvality, 1st ed.; Žilinská Univerzita: Žilina, Slovakia, 2012; ISBN 978-80-554-0601-5.

2. Murphy, M.; Jiang, N.; Han, Z.; Hazlett, D.; Baumanis, C.; Ahsan, A.S.; Machemehl, R.; Zhang, Z. Economic and Safety Considerations: Motor Vehicle Safety Inspections for Passenger Vehicles in Texas; Texas Department of Public Safety, Center for Transportation Research at the University of Texas at Austin: Austin, TX, USA, 2018.

3. Lejda, K.; Zielińska, E. Motor Vehicle Diagnosis in Terms of Technical Facilities Requirements. J. Pol. CIMAC 2013, 8, 61-70.

4. Fazzalaro, J. Periodic Motor Vehicle Safety Inspections; Connecticut General Assembly Office of Legislative Research: Hartford, CT, USA, 2007; 2007-R-0591. Available online: https:/ / www.cga.ct.gov/2007/rpt/2007-R-0591.htm (accessed on 30 November 2020).

5. GAO; United States Government Accountability Office. Vehicle Safety Inspections: Improved DOT Communication Could Better Inform State Programs; Report to the Honorable Claire McCaskill; Report No. GAO-15-7051; U.S. Senate: Washington, DC, USA, 2015.

6. Manitoba Infrastructure. The Official Website of Manitoba Province, Canada, Retrieved on 22 June 2018. Available online: http:/ / www.gov.mb.ca/mit/mcd/mcs/index.html (accessed on 30 November 2020).

7. Lukáč, S.; Marasová, D.; Mikušová, N.; Stopka, O. Quality management of information systems. Qual.-Access Success 2020, 21, 167-170.

8. Zovak, G.; Cala, I.; Sisko, I. Application of standards in auditing of stations for technical inspections of vehicles. Promet-Traffic Transp. 2009, 21, 191-198. [CrossRef]

9. Bogucki, M.; Staçzek, P.; Płaska, S. Methods of improving quality product and process using experimental techniques. In Proceedings of the Second International CAMT Conference (Centre for Advanced Manufacturing Technologies), Modern Trends in Manufacturing, Wroclaw, Poland, 20-21 February 2003; pp. 15-20.

10. Chovancova, M.; Klapita, V. Modeling the supply process using the application of selected methods of operational analysis. Open Eng. 2017, 7, 50-54. [CrossRef]

11. Ferrari, C.; Migliardi, A.; Tei, A. A bootstrap analysis to investigate the economic efficiency of the logistics industry in Italy. Int. J. Logist. Res. Appl. 2018, 21, 20-34. [CrossRef]

12. Gola, A. Reliability analysis of reconfigurable manufacturing system structures using computer simulation methods. Eksploat. Niezawodn.-Maint. Reliab. 2019, 21, 90-102. [CrossRef] 
13. Swić, A.; Wołos, D.; Gola, A.; Šmidová, N. Accuracy control in the process of low-rigidity elastic deformable shafts turning. Teh. Vjesn. -Tech. Gaz. 2019, 26, 927-934.

14. Stoma, M.; Dudziak, A.; Słowik, T.; Wasilewski, J.; Kuranc, A. Consumers' perception of food quality and safety in terms of buying processes. In Proceedings of the Farm Machinery and Processes Management in Sustainable Agriculture, Lublin, Poland, 22-24 November 2017; Lorencowicz, E., Uziak, J., Huyghebaert, B., Eds.; Repozytorium CeON, University of Warsaw: Warsaw, Poland, 2017; pp. 354-358.

15. Humić, R.; Abramović, B. Criteria for the quality of services of public interest organized by train operators. Transp. Res. Procedia 2019, 40, 259-264. [CrossRef]

16. Stoma, M.; Dudziak, A.; Spalek, S. Strategic simulation games in management teaching. In Proceedings of the 13th International Technology, Education and Development Conference (INTED2019), INTED Proceedings, Valencia, Spain, 11-13 March 2019; pp. 4020-4028.

17. Ngai, E.W.T.; Chau, D.C.K.; Poon, J.K.L.; To, C.K.M. Energy and utility management maturity model for sustainable manufacturing process. Int. J. Prod. Econ. 2013, 146, 453-464. [CrossRef]

18. Vaughan, R.G. Safety maintenance of road vehicles. In Proceedings of the Institution of Mechanical Engineers, Braking of Road Vehicles, Birdcage Walk, London, UK, 23-24 March 1993.

19. Droździel, P.; Winska, M.; Madlenak, R.; Szumski, P. Optimization of the position of the local distribution centre of the regional post logistics network. Transp. Probl. 2017, 12, 43-50. [CrossRef]

20. Simanová, L'; Stasiak-Betlejewska, R. Selected approaches to change management and logistics in Slovak enterprises. LOGI-Sci. J. Transp. Logist. 2018, 9, 51-60. [CrossRef]

21. Varhelyi, A. Road safety management-The need for a systematic approach. Open Transp. J. 2016, 10, 137-155. [CrossRef]

22. Drozdziel, P.; Wrona, R. Legal and utility problems of accidents on express roads and motorways. In Proceedings of the 11th International Science and Technical Conference Automotive Safety 2018, Casta, Slovakia, 18-20 April 2018.

23. Poliak, M.; Mrnikova, M.; Simurkova, P.; Medvid, P.; Poliakova, A.; Hernandez, S. Social law in road transport like tool safety road transport. In Proceedings of the 11th International Science and Technical Conference Automotive Safety 2018, Casta, Slovakia, 18-20 April 2018.

24. Jurecki, R.S.; Poliak, M.; Jaskiewicz, M.J. Young adult drivers: Simulated behaviour in a car-following situation. Promet-Traffic Transp. 2017, 29, 381-390. [CrossRef]

25. Ondrus, J.; Karoń, G. Video system as a psychological aspect of traffic safety increase. In Proceedings of the 17th International Conference on Transport Systems Telematics (TST), Katowice, Poland, 5-8 April 2017; Communications in Computer and Information Science. Volume 715, pp. 167-177. [CrossRef]

26. Veternik, M.; Gogola, M. Examining of correlation between demographic development of population and their travel behaviour. Procedia Eng. 2017, 192, 929-934. [CrossRef]

27. Bartuśka, L.; Stopka, O.; Lizbetin, J. Methodology for Determining the Traffic Volumes on Urban Roads in the Czech Republic. In Proceedings of 19th International Conference Transport Means 2015, Kaunas, Lithuania, 22-23 October 2015; pp. $215-218$.

28. Gnap, J.; Kupčuljaková, J.; Semanová, Š. Determination of time savings for passengers by applying the public passenger transport preference. Commun. Sci. Lett. Univ. Žilina 2018, 20, 3-8. [CrossRef]

29. Lizbetin, J.; Bartuśka, L. The influence of human factor on congestion formation on urban roads. Procedia Eng. 2017, 187, $206-211$. [CrossRef]

30. Madleňak, R.; Hoštáková, D.; Madleňakova, L.; Drozdziel, P.; Török, A. The Analysis of the Traffic Signs Visibility During Night Driving. Adv. Sci. Technol. Res. J. 2018, 12, 71-76. [CrossRef]

31. Matijosius, J.; Ciziuniene, K.; Petraska, A.; Sokolovskij, E. The comparison of the accident rates in heavy transport sectors of Europe and USA. In Proceedings of the Third International Conference on Traffic and Transport Engineering (ICTTE), Belgrade, Serbia, 24-25 November 2016; Cokorilo, O., Ed.; pp. 1097-1101.

32. Tišljarić, L.; Carić, T.; Abramović, B.; Fratrović, T. Traffic state estimation and classification on citywide scale using speed transition matrices. Sustainability 2020, 12, 2547. [CrossRef]

33. Abramović, B.; Lovrić, I.; Stupalo, V. Analysis of intermodal terminals service quality in the republic of Croatia. Promet-Traffic Transp. 2012, 24, 253-260. [CrossRef]

34. Kilikevicius, A.; Kilikeviciene, K.; Matijosius, J. Investigation of drivers' comfort factors influencing urban traffic safety. Lect. Notes Intell. Transp. Infrastruct. 2020, 159-165. [CrossRef]

35. Kohút, P.; Macurová, L'.; Rédl, M.; Ballay, M. Application of rectification method for processing of documentation from the place of road accident. Arch. Automot. Eng. Arch. Motoryz. 2020, 88, 37-46.

36. Makka, K.; Stachova, D.; Kampova, K. Assessment of the mobile risk source in road transport. Commun. Sci. Lett. Univ. Zilina 2019, 21, 68-73. [CrossRef]

37. Samociuk, W.; Krzysiak, Z.; Bukova, B.; Brumercikova, E.; Bakowski, H.; Krzywonos, L. Analysis of international transport of chemical products in the countries of the Visegrad Group. Przem. Chem. 2018, 97, 829-833. [CrossRef]

38. Zaranka, J.; Peceliunas, R.; Matijosius, J. Analysis of the influence of fatigue on passenger transport drivers' performance capacity. Transport 2012, 27, 351-356. [CrossRef] 
39. Bańka, M.; Droździel, P.; Nieoczym, A. Lashing methods-Mathematical basis of the process of selecting the number of lashings. In Proceedings of the 23rd International Scientific Conference on Transport Means 2019, Palanga, Lithuania, 2-4 October 2019; pp. 99-103.

40. Droździel, P.; Tarkowski, S.; Rybicka, I.; Wrona, R. Drivers' reaction time research in the conditions in the real traffic. Open Eng. 2020, 10, 35-47. [CrossRef]

41. Rievaj, V.; Vrábel, J.; Synak, F.; Bartuška, L. The effects of vehicle load on driving characteristics. Adv. Sci. Technol. Res. J. 2018, 12, 142-149. [CrossRef]

42. Rodzeń, A.; Stoma, M.; Kuranc, A. Examination of vehicle exhaust gas analyzers in the context of the quality of periodic vehicle technical tests. Przem. Chem. 2018, 97, 762-766. [CrossRef]

43. Sejkorová, M.; Verner, J.; Sejkora, F.; Hurtová, I.; Senkýřr, J. Analysis of operation wear of brake fluid used in a Volvo car. In Proceedings of the International Conference 2018: Transport Means, Trakai, Lithuania, 3-5 October 2018; Kaunas University of Technology: Kaunas, Lithuania, 2018; pp. 592-596.

44. Skrucany, T.; Kendra, M.; Kalina, T.; Jurkovič, M.; Vojtek, M.; Synák, F. Environmental comparison of different transport modes. Nase More 2018, 65, 192-196. [CrossRef]

45. Tarkowski, S.; Rybicka, I. Distraction of the driver and its impact on road safety. Transp. Res. Procedia 2020, 44, 196-203. [CrossRef]

46. Bartnik, G.; Krzysiak, Z.; Samociuk, W.; Łysiak, G.; Plizga, K.; Szmigielski, M.; Nieoczym, A.; Kaliniewicz, Z.; Brumerčik, F. Dokumentowanie spełniania wymagań w obszarze bezpieczeństwa technicznego na przykładzie dystrybucji paliw ciekłych. Przem. Chem. 2017, 96, 1039-1041. [CrossRef]

47. Directive 2014/45/EU of the European Parliament and of the Council of 3 April 2014 on Periodic. Available online: https: / / eur-lex.europa.eu/legal-content/EN/TXT/PDF/?uri=CELEX:32014L0045\&rid=5 (accessed on 20 November 2020).

48. Roadworthiness Tests for Motor Vehicles and Their Trailers and of Repealing Directive 2009/40/ES. Available online: https: //www.eumonitor.eu/9353000/1/j9vvik7m1c3gyxp/vi5uy1tr41z8 (accessed on 20 November 2020).

49. STN EN ISO/IEC 17020 Conformity Assessments. Requirements for the operation of various types of bodies performing inspection. Available online: https:/ / www.iso.org/obp/ui/\#iso:std:52994:en (accessed on 25 November 2020).

50. STN EN ISO 9001 Quality Management Systems. Available online: www.snas.sk (accessed on 25 October 2020).

51. Law no. 106/2018 Z. z. On the Operation of Vehicles in Road Traffic and on the Change and Amendment of Certain Laws in View of Later Regulations. In Slovak. Available online: https:/ / www.ssc.sk/en/legislation.ssc (accessed on 25 October 2020).

52. Decree of the Ministry of Transport and Construction of the Slovak Republic no. 137/2018 Z. z. Laying Down the Details of the Periodical Technical Inspection. In Slovak. Available online: https: / www.ssc.sk/en/legislation.ssc (accessed on 25 October 2020).

53. STN EN ISO 9001 Quality Management Systems, Requirements (ISO 9001) (01 0320). Available online: https:/ /www.iso.org/ standard/62085.html (accessed on 25 November 2020).

54. PTI in the Slovak Republic. Available online: www.mindop.sk (accessed on 25 October 2020).

55. Skrúcaný, T.; Gnap, J. Energy intensity and greenhouse gases production of the road and rail Cargo transport using a software in simulate the energy consumption of a train, Telematics-Support of transport. In Proceedings of the 14th International Conference on Transport Systems Telematics, Katowice/Kraków and Ustroń, Poland, 22-25 October 2014.

56. Number of Companies Operating PTIs by Number of Employees and Fulfilment of Quality Management Requirements. Available online: www.minv.sk (accessed on 25 October 2020).

57. Additional Checks on Vehicles of Categories M2 and M3 Intended for Passenger Transport. Available online: www.finstat.sk (accessed on 25 October 2020).

58. Methodological Instruction of the Ministry of Transport and Construction of the Slovak Republic No. 12/2018 on the License of the Inspector and Carrying Out the Expert Supervision of Compliance with Act No. 106/2018 Coll. on the Operation of Vehicles in Road Traffic as Amended. In Slovak. Available online: https://www.slov-lex.sk/static/vestniky/SK/RZ/MDVSR/V/2018/1 08/MP\%2012-2018.pdf (accessed on 5 October 2020).

59. Synák, F.; Kalašová, A.; Synák, J. Air filter and selected vehicle characteristics. Sustainability 2020, 12, 9326. [CrossRef]

60. Hoagland, A.; Woolley, T. It's No Accident: Evaluating the Effectiveness of Vehicle Safety Inspections. Contem. Econ. Policy 2018, 36, 607-628. [CrossRef]

61. Czerwinski, J.; Comte, P.; Engelmann, D.; Mayer, A.; Lutz, T.; Hensel, V. Considerations of periodical technical inspection of vehicles with deNOx systems. SAE Tech. Paper 2019. [CrossRef]

62. Tsybunov, E.; Shubenkova, K.; Buyvol, P.; Mukhametdinov, E. Interactive (Intelligent) Integrated System for the Road Vehicles' Diagnostics. In Proceedings of the 1st International Conference on Intelligent Transport Systems INTSYS 2017, Hyvinkää, Finland, 29-30 November 2017; Volume 222, pp. 195-204. [CrossRef]

63. Stopka, O.; Kampf, R.; Vrábel, J. Deploying the means of transport within the transport enterprises in the context of emission standards Transport means. In Proceedings of the 20th International Scientific Conference, Kaunas University of Technology, Juodkrante, Lithuania, 5-7 October 2016; pp. 185-190.

64. Gajek, A. Directions for the development of periodic technical inspection for motor vehicles safety systems. Arch. Automot. Eng. Arch. Motoryz. 2018, 80, 37-51. [CrossRef]

65. Results of the Evaluation of Vehicles at PTI Depending on the Method of Meeting the Requirements for Quality Management. Available online: www.testek.sk (accessed on 10 December 2020). 
66. Automated Information System for Technical Inspections. Available online: www.mindop.sk (accessed on 25 October 2020).

67. Karpushko, M.O.; Bartolomei, I.L.; Karpushko, E.N. To a question of the setting of measures for culvert repair during technical inspection. In Proceedings of the International Scientific Conference on Construction and Architecture: Theory and Practice for the Innovation Development 2019, CATPID 2019, Kislovodsk, Russia, 1-5 October 2019; Volume 698, p. 077005. [CrossRef]

68. Kravchenko, A.; Kravchenko, K. Monitoring of the technical condition of semi-trailer trucks. Arch. Automot. Eng. Arch. Motoryz. 2018, 81, 17-28. [CrossRef]

69. Ondrus, J.; Kolla, E. Practical Use of the Braking Attributes Measurements Results. In Proceedings of the 18th International Scientific Conference on LOGI, MATEC Web Conference, Ceske Budejovice, Czech Republic, 19 October 2017; Volume 134, p. 00044. [CrossRef] 